\title{
KARAKTERISTIK KONSUMEN DAN PREFERENSINYA TERHADAP ATRIBUT BERAS BERDASARKAN GOLONGAN TINGKAT PENDAPATAN DI KOTA PALEMBANG
}

\author{
Yunita ${ }^{1}$, Muhammad Arbi ${ }^{2}$ \\ ${ }^{12}$ Staf Pengajar Universitas Sriwijaya \\ Jl Palembang-Prabumulih Km 32 Indralaya OI, 30662
}

\begin{abstract}
This research was conducted on 150 respondents in Palembang were randomly selected based on the assumptions of community groups that have a high income group (50 respondents), a moderate income group (50 respondents), and a low income group (50 respondents). The purpose of this study is to describe the characteristics of consumers and analyze consumer preferences for rice attributes based on the household income level. This study uses a survey method, using a questionnaire as a guide for interviews. The results showed that the characteristics of rice consumers are generally at the age of 15-56 years, women, educated from those who do not go to school until college graduates, where the majority are housewives and state-owned enterprises employee, earning between < Rp1,000,000 to > Rp10.000,000 per month, average rice consumption of 1-10 kg/month to $51-60 \mathrm{~kg} / \mathrm{month}$. This shows three household groups levels, namely high, medium and low income groups that can influence the decision to choose and buy rice for consumption. Rice attributes include the level of rice stickiness, rice storability, rice flavor, aromatics, rice type, volume of fluffiness, rice heads, broken grains, "beras menir", "beras kapur", and color. Household consumer preferences based on the importance level of rice attributes for the very important category that are most selected in the high and middle income groups are the quality before rice becomes cooked rice, while the low income group is the rice storability factor. The preferences of household consumers based on the level of preference for the attribute of rice for the very like category most selected in the high-income group are the rice flavor, for the middle-income group are rice stickiness, and the low-income group is rice stickiness and rice heads.
\end{abstract}

Key words: Characteristics, rice attributes and consumer preferences.

\begin{abstract}
ABSTRAK
Kajian dilakukan terhadap 150 responden yang bermukim di wilayah Kota Palembang yang dipilih secara acak berdasarkan asumsi kelompok masyarakat yang memiliki golongan pendapatan tinggi (50 responden), golongan pendapatan sedang (50 responden), dan golongan pendapatan rendah (50 responden). Tujuan kajian adalah untuk mendeskripsikan karakteristik konsumen dan menganalisis preferensi konsumen terhadap atribut beras berdasarkan golongan tingkat pendapatan rumah tangga di Kota Palembang. Kajian dirancang dengan metode survey, menggunakan kuisioner sebagai pedoman wawancara terhadap responden. Hasil penelitian diketahui bahwa Karakteristik konsumen beras berdasarkan golongan tingkat pendapatan rumah tangga di Kota Palembang pada umumnya memiliki usia antara 15-56 tahun, berjenis kelamin perempuan, berpendidikan dari yang Tidak Bersekolah sampai ada yang Lulus Perguruan Tinggi, mayoritas berprofesi sebagai ibu rumah tangga dan BUMN, berpendapatan antara $<$ Rp1.000.000,- sampai dengan >Rp10.000.000,- per bulan, dengan rata-rata konsumsi beras antara 1-10 Kg/bulan sampai dengan 51-60 Kg/bulan. Hal ini menunjukkan bahwa karakteristik rumah tangga dari ketiga tingkat golongan, baik dari golongan pendapatan tinggi, sedang maupun rendah sangat beragam yang mana karakteristik ini dapat mempengaruhi keputusan
\end{abstract}


memilih dan membeli beras yang akan dikonsumsi. Atribut beras mencakup tingkat kepulenan nasi, daya tahan simpan nasi, rasa nasi, aromatic, jenis beras, volume keterkembangan, beras kepala, butir patah, butir menir, butir kapur, dan warna. Preferensi konsumen rumah tangga berdasarkan tingkat kepentingan atribut beras untuk kategori sangat penting yang paling banyak dipilih pada golongan pendapatan tinggi dan sedang adalah kualitas sebelum beras tersebut menjadi nasi, sedangkan golongan pendapatan rendah adalah factor ketahanan pada nasi. Preferensi konsumen rumah tangga berdasarkan tingkat kesukaan atribut beras untuk kategori sangat suka yang paling banyak dipilih pada golongan pendapatan tinggi adalah rasa nasi, untuk golongan pendapatan menengah adalah kepulenan nasi, dan golongan pendapatan rendah adalah kepulenan nasi dan beras kepala.

Kata kunci: Karakteristik, atribut beras dan preferensi konsumen.

\section{PENDAHULUAN}

Pangan sebagai sumber karbohidrat merupakan salah satu kebutuhan dasar bagi kelangsungan hidup manusia. Beras sebagai bahan pangan penghasil karbohidrat terbesar telah dikonsumsi lebih dari separuh penduduk dunia atau sekitar 26 negara diantaranya China, India, Pakistan, Bangladesh, Malaysia, Thailand, Vietnam, Indonesia dan negara berpenduduk padat lainnya. Di negara Indonesia, hampir $98 \%$ penduduknya mengkonsumsi beras dengan memiliki tingkat konsumsi yang melebihi tingkat konsumsi bahan pangan pokok lainnya seperti ubi, sagu, jagung, dengan nilai diatas 1,6 kg/kapita/minggu (BPS-Statistics Indonesia, 2018)

Ditinjau dari sisi konsumsi, beras merupakan komoditi penting karena sebagian besar mengkonsumsi beras sebagai bahan pangan utama sehari-hari. Konsumsi beras di Sumatera Selatan dari Januari hingga Desember 2018 diperkirakan sekitar 824,29 ribu ton, lebih rendah jika dibandingkan dengan produksi beras dari Januari hingga Desember 2018 sebesar 1,5 juta ton. Dengan demikian, surplus produksi beras di Sumatera Selatan pada tahun 2018 diperkirakan sekitar 687,69 ribu ton. Konsumsi per kapita menggunakan angka rata-rata konsumsi per kapita per provinsi tahun 2017. Rata-rata konsumsi nasional adalah 111,58 $\mathrm{Kg} / \mathrm{Kapita} / \mathrm{Tahun}$. Sedangkan jumlah penduduk menggunakan proyeksi penduduk pertengahan tahun 2018 (BPS Sumatera Selatan, 2019).

Kota Palembang merupakan kota terbesar di Sumatera Selatan dengan penduduk 1.580.517 jiwa dan tingkat kepadatan mencapai $3.945 \mathrm{jiwa} / \mathrm{Km}^{2}$. Dengan jumlah penduduk yang cukup besar maka akan diiringi dengan tingkat konsumsi pangan yang cukup tinggi. Besarnya permintaan dan konsumsi beras pada masyarakat tentunya juga berpengaruh pada besarnya pengeluaran konsumen untuk membeli kebutuhan pangan. Selain itu beras merupakan konsumsi sehari - hari yang merupakan bahan pangan pokok bagi sebagian besar masyarakat Kota Palembang.

Mata pencaharian penduduk kota Palembang sangat beragam, sehingga jumlah pendapatan yang diperoleh dari setiap penduduk berbeda-beda. Oleh karena itu, konsumsi rumah tangga secara langsung akan dipengaruhi oleh pendapatan rumah tangga. Konsumsi pangan akan berbeda pada setiap tingkat pendapatan yaitu pendapatan tinggi, sedang dan rendah. Pendapatan juga merupakan salah satu faktor penting yang mempengaruhi perilaku konsumen dalam pembelian serta mengkonsumsi. Sebagian konsumen mengutamakan kualitas dari atribut suatu produk tersebut. Perbedaan kualitas dan harga membuat masyarakat bisa memilih beras dengan kualitas yang dia inginkan serta jumlah konsumsi yang dikonsumsi. Konsumen menginginkan beras sesuai dengan preferensinya. Dalam melakukan pembelian beras, konsumen akan selalu memperhatikan atribut-atribut yang melekat pada beras.

Penelitian terkjait perferensi konsumen pada beras dan atributnya telah banyak dilakukan, antara lain (Hendaris, Zakaria, \& Kasymir, 2013; Kamila \& Prasetyo, 2019; Nurjaya \& Maulida, 2018; Sumarwan, U., 2013; Swastika, Yanto, \& Hartati, 2013). Berdasarkan hasil penelitian-penelitian tersebut diketahui bahwa atribut yang digunakan konsumen beras mencakup aroma, kepulenan, butir utuh dan kemurnian. Sementara terkait dengan prilaku, 
konsumen di pasar tradisional atribut beras yang dipilih konsumen mencakup fisik beras yakni bentuk bulir, aroma, kemasan dan harga. Dari uraian diatas maka masih ada celah penelitian terkait preferensi konsumen beras pada berbagai tingkat pendapatan. permasalahan yang menarik untuk diteliti adalah bagaimana preferensi konsumen berdasarkan atribut beras terhadap pendapatan masyarakat yang tinggal di wilayah Kota Palembang. Penelitian tentang prilaku dan konsumsi beras sudah banyak dilakukan, namun urgensi dari penelitian ini memiliki kecenderungan ke arah rekomendasi permasalahan terkait atribut beras dengan lebih memfokuskan kepada karakteristik tingkat golongan masyarakat berpendapatan rendah, menengah, dan berpendapatan tinggi.

Berdasarkan uraian tersebut, maka permasalahan yang menarik untuk diteliti adalah bagaimana karakteristik konsumen berdasarkan golongan pendapatan rumah tangga di Kota Palembang. bagaimana preferensi konsumsen terhadap atribut beras berdasarkan tingkat golongan pendapatan rumah tangga di Kota Palembang. Hasil penelitian ini diharapkan berguna sebagai bahan pertimbangan bagi pemerintah setempat untuk menentukan kebijakan terkait perberasan di wilayah Kota Palembang.

\section{METODE PENELITIAN}

Penelitian didesain dengan metode survei dan dilaksanakan di pemukiman penduduk rumah tangga di wilayah Kota Palembang pada bulan September 2019 terhadap 150 responden. Metode penarikan sampel dalam penelitian ini menggunakan teknik probability sampling yaitu teknik pengambilan sampel yang memberikan peluang sama bagi setiap unsur (anggota) populasi untuk dipilih menjadi anggota sampel. Jenis teknik probability sampling yang digunakan adalah teknik Cluster Sampling (Area Sampling). (Sugiono, 2015) menjelaskan bahwa cluster sampling adalah teknik sampling daerah digunakan untuk menentukan sampel bila obyek yang akan diteliti atau sumber data sangat luas. Dikarenakan kecamatan-kecamatan di Palembang bestrata atau tidak sama maka pengambilan sampel perlu menggunakan stratified random sampling berdasarkan tingkat pendapatan. Kecamatan yang menjadi sampling adalah Kecamatan Sako, Kecamatan Sematang Borang dan Kecamatan Kalidoni. Kecamatan Sako mewakili konsumen dengan pendapatan rendah yaitu perumahan RSS Griya Harapan A, Kecamatan Ilir Timur II dengan pendapatan menengah adalah Komplek Perumahan BULOG dan Kecamatan Kalidoni mewakili konsumen dengan pendapatan tinggi yaitu perumahan Komplek PT Pusri. Jumlah rumah tangga sampel dalam penelitian ini masing-masing 50 rumah tangga sehingga total menjadi sebanyak 150 rumah tangga. Untuk mendapatkan data primer maupun sekunder, dilakukan wawancara dengan berpedoman pada kuisioner yang telah disusun.

Peubah yang diteliti meliputi preferensi konsumen rumah tangga berdasarkan atribut beras pada beberapa golongan pendapatan rumah tangga konsumen rumah tangga di wilayah Kota PalembangBeberapa atribut yang digunakan mengacu pada penelitian (Kamila \& Prasetyo, 2019; Sari PA., 2016; Syahrir, 2015).

\section{HASIL DAN PEMBAHASAN}

\section{Data Responden}

Penduduk di Kota Palembang yaitu sebanyak 1.623.099, dimana mengalami peningkatan jumlah penduduk pada tahun sebelumnya. Jumlah penduduk Kota Palembang pada tahun 2016 sebanyak 1.602.071 jiwa. Ini menunjukkan bahwa jumlah penduduk di Kota Palembang mengalami peningkatan yaitu sebanyak 21.028 jiwa. Karateristik responden yang diambil dalam penelitian ini adalah konsumen rumah tangga yang membeli beras yang terdiri dari 3 lapisan yaitu konsumen rumah tangga pendapatan rendah, menengah dan tinggi yang ada di Kota Palembang. Jumlah responden yang diambil adalah sebanyak 50 orang pada setiap kosumen rumah tangga baik pada konsumen pendapatan rendah, menengah dan tinggi.

\section{a. Karakteristik Responden Berdasarkan Usia}


Usia merupakan salah satu faktor yang dapat mempengaruhi selera para konsumen dalam membeli beras karena adanya perbedaan usia konsumen satu sama lainnya. Perbedaan usia dapat mempengaruhi cara berpikir seseorang dalam mempengaruhi keputusan konsumen dalam membeli beras.

Tabel 1. Sebaran Responden Berdasarkan Usia.

\begin{tabular}{cccccccc}
\hline No & $\begin{array}{c}\text { Tingkat Umur } \\
\text { (tahun) }\end{array}$ & $\begin{array}{c}\text { Pendapatan } \\
\text { Rendah }\end{array}$ & \multicolumn{2}{c}{ Pendapatan Menengah } & $\begin{array}{c}\text { Pendapatan } \\
\text { Tinggi }\end{array}$ \\
& & Jumlah & $(\%)$ & Jumlah & $(\%)$ & Jumlah & $(\%)$ \\
\hline 1 & $15-56$ & 35 & 70 & 48 & 96 & 50 & 100 \\
2 & $57-65$ & 8 & 16 & 1 & 2 & 0 & 0 \\
3 & $>65$ & 7 & 14 & 1 & 2 & 0 & 0 \\
\hline \multicolumn{2}{c}{ Jumlah } & $\mathbf{5 0}$ & $\mathbf{1 0 0}$ & $\mathbf{5 0}$ & $\mathbf{1 0 0}$ & $\mathbf{5 0}$ & $\mathbf{1 0 0}$ \\
\hline
\end{tabular}

Sumber : Data Monografi Desa, Tahun 2019

\section{b. Karakteristik Responden Berdasarkan Jenis}

\section{Kelamin}

Jenis kelamin merupakan salah satu karakteristik yang dapat mempengaruhi para konsumen dalam membeli beras untuk kebutuhan sehari-hari. Karakteristik konsumen berdasarakan jeni kelamin dibagi menjadi 2 kelompok yaitu, laki-laki dan perempuan. Umumnya, jenis kelamin dapat menunjukkan perbedaan selera dan kebiasaan para konsumen dalam membeli beras. Karakteristik responden berdasarkan jenis kelamin dapat dilihat pada Tabel di bawah ini;.

Tabel 2. . Karakteristik Responden Berdasarkan Jenis Kelamin.

\begin{tabular}{|c|c|c|c|c|c|c|c|}
\hline \multirow{2}{*}{ No } & \multirow{2}{*}{$\begin{array}{c}\text { Jenis } \\
\text { Kelamin }\end{array}$} & \multicolumn{2}{|c|}{ Pendapatan Rendah } & \multicolumn{2}{|c|}{$\begin{array}{c}\text { Pendapatan } \\
\text { Menengah }\end{array}$} & \multicolumn{2}{|c|}{ Pendapatan Tingg } \\
\hline & & $\begin{array}{c}\text { Jumlah } \\
\text { (org) }\end{array}$ & $(\%)$ & $\begin{array}{c}\text { Jumlah } \\
\text { (org) }\end{array}$ & $(\%)$ & $\begin{array}{c}\text { Jumlah } \\
\text { (org) }\end{array}$ & $(\%)$ \\
\hline 1 & Laki-Laki & 5 & 10 & 17 & 34 & 34 & 68 \\
\hline 2 & Perempuan & 45 & 90 & 33 & 66 & 16 & 32 \\
\hline & Jumlah & 50 & 100 & 50 & 100 & 50 & 100 \\
\hline
\end{tabular}

Sumber : Data Monografi Desa di Wilayah Studi, 2019

Diketahui bahwa karateristik responden berdasarakan jenis kelamin didominasi oleh perempuan yaitu pada pendapatan rendah sebesar $90 \%$ dan pendapatan menengah sebesar $66 \%$. Sedangkan untuk pendapatan tinggi didominasi oleh laki laki yaitu sebsar $68 \%$.

\section{c. Karakteristik Responden Berdasarkan Tingkat Pendidikan}

Semakin tinggi tingkat pendidikan maka semakin luas pengetahuan dan informasi yang diketahui dan cenderung memiliki cara berpikir yang lebih baik dalam mengambil keputusan. Karakteristik responden berdasarkan pendidikan dibagi menjadi 5 kelompok yaitu, SD, SMP, SMA, Diploma dan Sarjana. 
Tabel 3. Karakteristik Responden Berdasarkan Tingkat Pendidikan

\begin{tabular}{clcccccc}
\hline No & $\begin{array}{c}\text { Tingkat } \\
\text { Pendidikan }\end{array}$ & \multicolumn{2}{c}{$\begin{array}{c}\text { Pendapatan } \\
\text { Rendah }\end{array}$} & \multicolumn{2}{c}{ Pendapatan Menengah } & \multicolumn{2}{c}{$\begin{array}{c}\text { Pendapatan } \\
\text { Tinggi }\end{array}$} \\
& & Jumlah & $(\boldsymbol{\%})$ & Jumlah & $(\boldsymbol{\%})$ & Jumlah & $(\boldsymbol{\%})$ \\
\hline 1 & Tidak Bersekolah & 1 & 2 & 0 & 0 & 0 & 0 \\
2 & SD & 5 & 10 & 0 & 0 & 0 & 0 \\
3 & SMP & 14 & 28 & 0 & 0 & 0 & 0 \\
4 & SMA/SMU & 24 & 48 & 5 & 10 & 8 & 16 \\
5 & Diploma & 1 & 2 & 3 & 6 & 9 & 18 \\
6 & Sarjana & 5 & 10 & 32 & 64 & 27 & 54 \\
7 & Pascasarjana & 0 & 0 & 10 & 20 & 6 & 12 \\
\hline Jumlah & $\mathbf{5 0}$ & $\mathbf{1 0 0}$ & $\mathbf{5 0}$ & $\mathbf{1 0 0}$ & $\mathbf{5 0}$ & $\mathbf{1 0 0}$ \\
\hline
\end{tabular}

Sumber: Hasil survey, 2019

Pada konsumen pendapatan rendah, didominasi oleh tingkat pendidikan SMA/SMU sebesar $48 \%$, sedangkan untuk konsumen rumah tangga pendapatan menengah dan tinggi didominasi oleh tingkat pendidikan sarjana yaitu $64 \%$ dan 54\%. Hal ini menunjukkan bahwa pada konsumen rumah tangga pendapatan rendah cenderung kesadaran pada pendidikannya masih rendah, sedangkan pada konsumen rumah tangga pendapatan menengah dan tinggi menyadari bahwa tingkat pendidikan sangat penting karena lebih dari setengah jumlah konsumen rumah tangga yang ada telah menjadi sarjana dan pascsarjana.

\section{d. Karakteristik Responden Berdasarkan Pekerjaan}

Pekerjaan adalah salah satu hal yang dapat menentukan preferensi para konsumen untuk memlih dan membeli beras karena pekerjaan secara tidak langsung mempengaruhi pendapatan rumah tangga para konsumen. Karakteristik konsumen berdasarkan pekerjaan terdiri dari pegawai negeri (PNS), Pegawai Swasta, BUMN/BUMD, wirawasta, pegawai swasta, ibu rumah tangga dan lainnya.

Tabel 4. Karakteristik Responden Berdasarkan Pekerjaan Utama

\begin{tabular}{llcccccc}
\hline No & Pekerjaan & $\begin{array}{c}\text { Pendapatan } \\
\text { Rendah } \\
\text { Jumlah } \\
\text { (org) }\end{array}$ & $\begin{array}{c}\text { Pendapatan Menengah } \\
\text { Jumlah }\end{array}$ & $\begin{array}{c}\text { Pendapatan Tinggi } \\
\text { (org) }\end{array}$ & $(\%)$ & $\begin{array}{c}\text { Jumlah } \\
\text { (org) }\end{array}$ & $(\%)$ \\
\hline & Pegawai Negeri & & & & & & \\
1 & (PNS) & 0 & 0 & 22 & 44 & 0 & 0 \\
2 & Pegawai Swasta & 0 & 0 & 0 & 0 & 0 & 0 \\
3 & BUMN/BUMD & 0 & 0 & 28 & 56 & 33 & 66 \\
4 & Wiraswasta & 6 & 12 & 0 & 0 & 12 & 24 \\
& Ibu Rumah & & & & & & \\
5 & Tangga & 32 & 64 & 0 & 0 & 0 & 0 \\
6 & Lainnya & 12 & 24 & 0 & 0 & 5 & 10 \\
\hline & Jumlah & $\mathbf{5 0}$ & $\mathbf{1 0 0}$ & $\mathbf{5 0}$ & $\mathbf{1 0 0}$ & $\mathbf{5 0}$ & $\mathbf{1 0 0}$ \\
\hline
\end{tabular}

Sumber: Hasil survey, 2019

Pada konsumen rumah tangga pendapatan rendah yang paling mendominasi adalah sebagai ibu rumah tangga sebesar 64\%, pada konsumen rumah tangga pendapatan menengah yang paling mendominasi adalah yang bekerja di BUMN/BUMD sebesar 56\% dan pada konsumen rumah tangga pendapatan tinggi yang paling mendominasi adalah yang bekerja sebagai pengawai negeri sipil (PNS). Hal ini menunjukkan bahwa pekerjaan yang paling 
mendominasi secara keseluruhan adalah ibu rumah tangga, BUMN/BUMD dan Pengawai negeri (PNS).

\section{e. Karakteristik Responden Berdasarkan Pendapatan}

Pendapatan dapat menentukan kualitas yang diinginkan konsumen dalam membeli beras. Karakteristik responden yang membeli beras berdasarkan pendapatan dibagi menjadi 4 kategori yaitu kategori 1 pada pendapatan yang kurang dari $\mathrm{Rp} 1.000 .000$ ), kategori ke 2 yaitu $\mathrm{Rp}$ 1.000.001-2.500.000, kategori yang ketiga yaitu Rp 2.500.001 - 5.000.000, kategori 4 yaitu Rp5.000.001-7.500.000, kategori 5 yaitu 7.500.001-10.000.000 dan kategori 6 yaitu lebih dari Rp10.000.000.

Tabel 5. Karakteristik Responden Berdasarkan Pekerjaan Utama

\begin{tabular}{|c|c|c|c|c|c|c|c|}
\hline \multirow[b]{2}{*}{ No } & \multirow[b]{2}{*}{ Pendapatan (bulan) } & \multicolumn{2}{|c|}{ Pendapatan Rendah } & \multicolumn{2}{|c|}{$\begin{array}{c}\text { Pendapatan } \\
\text { Menengah }\end{array}$} & \multicolumn{2}{|c|}{$\begin{array}{c}\text { Pendapatan } \\
\text { inggi }\end{array}$} \\
\hline & & $\begin{array}{l}\text { Jumla } \\
\text { h (org) }\end{array}$ & $(\%)$ & $\begin{array}{c}\text { Jumlah } \\
\text { (org) }\end{array}$ & $(\%)$ & $\begin{array}{c}\text { Jumlah } \\
\text { (org) }\end{array}$ & $(\%)$ \\
\hline 1 & $<1.000 .000$ & 4 & 8 & 0 & 0 & 0 & 0 \\
\hline 2 & $1.000 .001-2.500 .000$ & 33 & 66 & 0 & 0 & 0 & 0 \\
\hline 3 & $2.500 .001-5.000 .000$ & 13 & 26 & 2 & 4 & 8 & 16 \\
\hline 4 & $5.000 .001-7.500 .000$ & 0 & 0 & 20 & 40 & 10 & 20 \\
\hline 5 & $\begin{array}{l}7.500 .001- \\
10.000 .000\end{array}$ & 0 & 0 & 13 & 26 & 15 & 30 \\
\hline 6 & $>10.000 .000$ & 0 & 0 & 15 & 30 & 17 & 34 \\
\hline & Total & 50 & 100 & $\mathbf{5 0}$ & 100 & 50 & 100 \\
\hline
\end{tabular}

Sumber: Hasil survey, 2019

Pada konsumen rumah tangga pendapatan rendah, pendapatan yang mendominasi yaitu Rp1.000.001-2.500.000 sebesar 66\%, pada konsumen rumah tangga pendapatan menengah yaitu Rp 5.000.001-7.500.000 sebesar 40\%, dan pada konsumen rumah tangga pendapatan tinggi yaitu lebih dari Rp10.000.000 sebesar 34\%. Hal ini menunjukkan bahwa pendapatan rumah tangga dari ketiga lapisan, baik pada konsumen rumah tangga pendapatan rendah, menengah, dan tinggi sangat beragam. Pendapatan konsumen rumah tangga dapat mempengaruhi para konsumen dalam membeli beras karena besarnya pendapatan akan menjadi bahan pertimbangan konsumen dalam mengambil suatu keputusan untuk memilih dan membeli beras yang akan dikonsumsi. Pendapatan akan mempengaruhi daya beli konsumen terhadap beras yang akan dikonsumsi.

\section{f. Karakteristik Responden Berdasarkan Konsumsi Beras}

Konsumsi beras adalah banyaknya beras yang dikonsumsi konsumen rumah tangga per bulannya untuk memenuhi kebutuhan sehari-hari. Konsumsi beras yang dikonsumsi mulai berkisar antara 1 hingga $60 \mathrm{~kg}$ perbulannya. 
Tabel 6. Karakteristik Responden Berdasarkan Konsumsi Beras

\begin{tabular}{cccccccc}
\hline No & $\begin{array}{c}\text { Konsumsi Beras } \\
(\mathbf{K g})\end{array}$ & $\begin{array}{c}\text { Pendapatan Rendah } \\
\text { Jumlah } \\
\text { (org) }\end{array}$ & $\begin{array}{c}\text { Pendapatan } \\
\text { Menengah }\end{array}$ & $\begin{array}{c}\text { Pendapatan } \\
\text { Tumlah } \\
\text { Tinggi }\end{array}$ \\
\hline 1 & 0 & 0 & 0 & 0 & $(\%)$ & $\begin{array}{c}\text { Jumlah } \\
\text { (org) }\end{array}$ & $(\%)$ \\
2 & $1-10$ & 7 & 14 & 20 & 40 & 18 & 2 \\
3 & $11-20$ & 32 & 64 & 20 & 40 & 25 & 50 \\
4 & $21-30$ & 10 & 20 & 4 & 8 & 4 & 8 \\
5 & $31-40$ & 1 & 2 & 3 & 6 & 1 & 2 \\
6 & $41-50$ & 0 & 0 & 1 & 2 & 1 & 2 \\
7 & $51-60$ & 0 & 0 & 2 & 4 & 0 & 0 \\
\hline & Jumlah & $\mathbf{5 0}$ & $\mathbf{1 0 0}$ & $\mathbf{5 0}$ & $\mathbf{1 0 0}$ & $\mathbf{5 0}$ & $\mathbf{1 0 0}$ \\
\hline
\end{tabular}

Sumber: Hasil survey, 2019

Pada konsumen rumah tangga pendapatan rendah, konsumen beras yang mendominasi yaitu 11-20 kg perbulannya dengan persentase sebesar $64 \%$, pada konsumen rumah tangga pendapatan menengah yaitu berkisar antara $11-30 \mathrm{~kg}$ perbulannya dengan persentase sebesar $40 \%$ dan pada konsumen rumah tangga pendapatan tinggi yaitu antra 11-20 kg perbulannya dengan persentase sebesar yaitu lebih dari sebesar 50\%. Hal ini menunjukkan bahwa kecendrungan mengkonsumsi beras dalam jumlah yang pada konusmen rumah tangga pendapatan rendah, menengah dan tinggi yaitu berkisar antara 11-20 kg. Kebutuhan dalam konsumsi beras pun dapat dipengaruhi oleh jumlah anggota keluarga, apabila jumlah anggota keluarga banyak, maka konsumsi beras akan tinggi begitupun sebaliknya, karena beras merupakan makanan pokok yang dibutuhkan dalam kehidupan sehari-hari.

\section{Preferensi Konsumen Berdasarkan Atribut Beras yang ada di Kota Palembang}

Preferensi konsumen berdasarkan atribut beras terdiri dari tingkat kepentingan, tingkat kesukaan dan tingkat kinerja yang dipilih dari para konsumen. Terdapat 3 golongan konsumen rumah tangga yaitu konsumen rumah tangga pendapatan rendah, menengah, dan tinggi.

\section{a. Preferensi Konsumen Berdasarkan Tingkat Kepentingan Atribut Beras}

Preferensi konsumen berdasarkan tingkat kepentingan atribut beras merupakan tingkatan yang berisi daftar atribut-atribut beras berdasarkan tingkat kepentingan para konsumen beras di Kota Palembang dalam memilih dan membeli beras berdasarkan atribut-atribut beras yang ada. Dalam hal ini terdapat 3 lapisan konsumen beras yang terdiri konsumen rumah tangga pendapatan rendah, menengah dan tinggi. 
Tabel 7. Preferensi Konsumen Beras Berdasarkan Tingkat Kepentingan Atribut-Atribut Beras

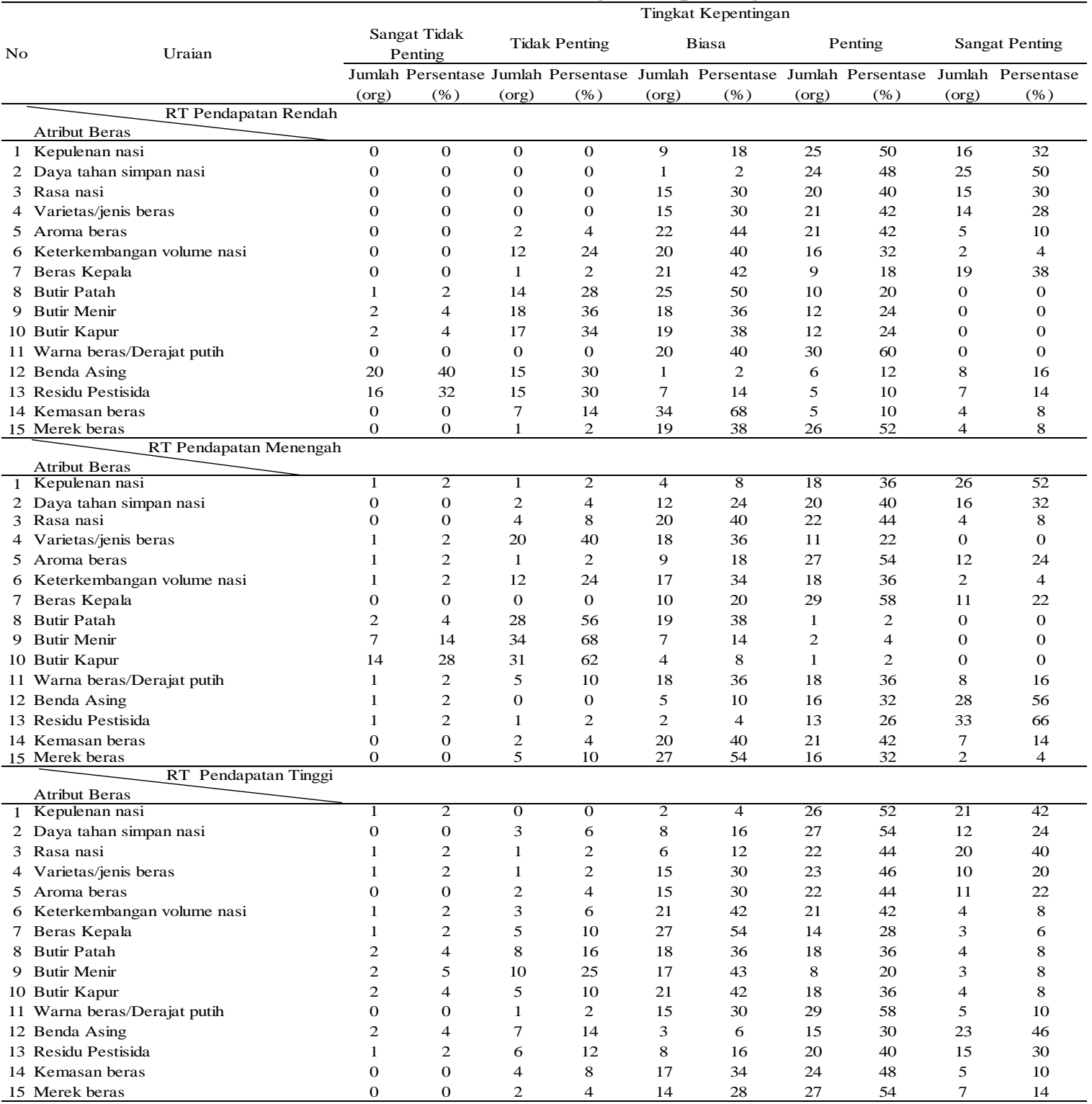

Sumber: Hasil survey, 2019

Preferensi konsumen rumah tangga terhadap atribut yang diambil adalah yang paling banyak dipilih oleh konsumen, ketika mereka ingin membeli beras untuk kebutuhan sehari-hari. Dalam membeli beras tersebut terdapat kategori-kategori yang dipilih yaitu mulai dari kategori yang sangat penting, penting, biasa, tidak penting, dan sangat tidak penting.

Preferensi konsumen rumah tangga terhadap atribut beras untuk kategori sangat penting yang paling banyak dipilih pada rumah tangga pendapatan rendah yaitu daya tahan simpan nasi sebanyak 25 orang dengan persentase $50 \%$, untuk rumah tangga pendapatan menengah yaitu atribut residu pestisida sebanyak 33 orang dengan persentase $66 \%$, dan rumah tangga pendapatan tinggi yaitu atribut benda asing sebanyak 23 orang dengan persentase $46 \%$. Hal ini menunjukkan bahwa tingkat kepentingan para konsumen terhadap atribut-atribut beras sangat bervariasi. Pada konsumen rumah tangga pendapatan rendah lebih cenderung memilih ketahanan pada nasi, sedangkan untuk konsumen rumah tangga pendapatan menengah dan tinggi cenderung memilih hal terkait kualitas sebelum beras tersebut menjadi nasi.

Preferensi konsumen rumah tangga terhadap atribut beras untuk kategori penting yang paling banyak dipilih pada rumah tangga pendapatan rendah yaitu atribut warna/derajat putih 
sebanyak 30 orang dengan persentase $60 \%$, rumah tangga pendapatan menengah yaitu atribut beras kepala sebanyak 29 orang dengan persentase 58\%, dan konsumen rumah tangga pendapatan tinggi yaitu atribut warna/derajat putih sebanyak 29 orang dengan persentase $58 \%$. Hal ini menunjukkan bahwa adanya kesamaan preferensi pada konsumen rumah tangga pendapatan rendah dan tinggi terhadap atribut beras yaitu warna/derajat putih, sedangkan berbeda dengan konsumen rumah tangga pendapatan menengah.

Preferensi konsumen rumah tangga terhadap atribut beras untuk kategori biasa yang paling banyak dipilih pada rumah tangga pendapatan rendah yaitu atribut kemasan beras sebanyak 34 orang dengan persentase $68 \%$, rumah tangga pendapatan menengah yaitu atribut merk beras sebanyak 27 orang dengan persentase $54 \%$, dan konsumen rumah tangga pendapatan tinggi yaitu atribut beras kepala sebanyak 27 orang dengan persentase 54\%. Hal ini menunjukkan bahwa preferensi konsumen rumah tangga baik konsumen rumah tangga pendapatan rendah, menengah dan tinggi terhadap pemilihan atribut-atribut beras sangat bervariasi.

Preferensi konsumen rumah tangga terhadap atribut beras untuk kategori tidak penting yang paling banyak dipilih pada rumah tangga pendapatan rendah yaitu atribut butir menir sebanyak 18 orang dengan persentase $36 \%$, rumah tangga pendapatan menengah yaitu atribut butir menir sebanyak 34 orang dengan persentase 68\%, dan konsumen rumah tangga pendapatan tinggi yaitu atribut butir menir sebanyak 10 orang dengan persentase $25 \%$. Hal ini menunjukkan bahwa preferensi konsumen rumah tangga baik konsumen rumah tangga pendapatan rendah, menengah dan tinggi memiliki kesamaan dalam memlih atribut beras yang tidak penting yaitu atribut butir menir.

Preferensi konsumen rumah tangga terhadap atribut beras untuk kategori sangat tidak penting yang paling banyak dipilih pada rumah tangga pendapatan rendah yaitu atribut benda asing sebanyak 20 orang dengan persentase $40 \%$, rumah tangga pendapatan menengah yaitu atribut butir kapur sebanyak 14 orang dengan persentase $28 \%$, dan konsumen rumah tang ga pendapatan tinggi yaitu atribut butir menir, butir patah, butir kapur dan benda asing hanya 2 orang dengan persentase $4 \%$ yang sangat sedikit sekali yang memilih. Hal ini menunjukkan bahwa preferensi konsumen rumah tangga baik konsumen rumah tangga pendapatan rendah, menengah dan tinggi sangat bervariasi dalam memlih atribut beras tersebut, dan pada konsumen rumah tangga pendapatan tinggi tidak terlalu banyak memilih kategori ini.

\section{b. Preferensi Konsumen Berdasarkan Tingkat Kesukaan Atribut Beras}

Preferensi konsumen berdasarkan tingkat kesukaan atribut beras merupakan tingkatan yang berisi daftar atribut-atribut beras berdasarkan tingkat kesukaan para konsumen beras di Kota Palembang dalam memilih dan membeli beras berdasarkan atribut-atribut beras yang ada. Dalam hal ini terdapat 3 lapisan konsumen beras yang terdiri konsumen rumah tangga pendapatan rendah, menengah dan tinggi. 
Tabel 8. Preferensi Konsumen Beras Berdasarkan Tingkat Kesukaan Atribut-Atribut Beras

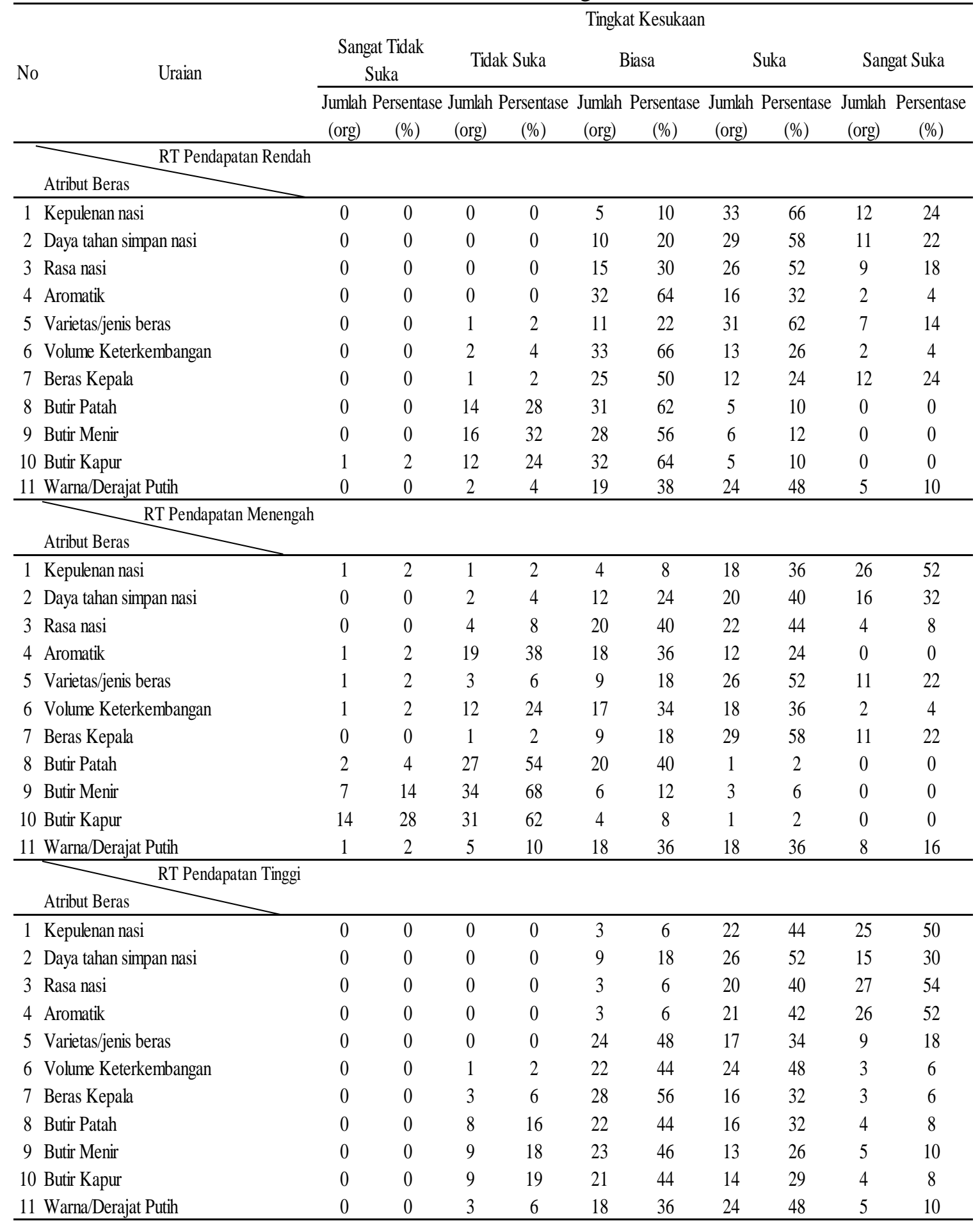

Sumber: Hasil survey, 2019

Tingkat kesukaan juga mempengaruhi para konsumen untuk memilih dan membeli beras. Dalam membeli beras tersebut terdapat kategori-kategori yang dipilih yaitu mulai dari kategori sangat suka, suka, biasa, tidak suka dan sangat tidak suka.

Preferensi konsumen rumah tangga terhadap atribut beras untuk kategori sangat suka yang paling banyak dipilih pada rumah tangga pendapatan rendah yaitu kepulenan nasi dan beras kepala sebanyak 12 orang dengan persentase $24 \%$, untuk rumah tangga pendapatan 
menengah yaitu atribut kepulenan nasi sebanyak 26 orang dengan persentase 52\%, dan untuk pendapatan tinggi yaitu atribut rasa nasi sebanyak 27 orang dengan persentase $54 \%$. Hal ini menunjukkan bahwa adanya kesamaan preferensi pada konsumen rumah tangga pendapatan rendah dan menengah terhadap atribut beras yaitu kepulenan nasi, sedangkan berbeda dengan konsumen rumah tangga pendapatan tinggi yang lebih kepada atribut rasa nasi.

Preferensi konsumen rumah tangga terhadap atribut beras untuk kategori suka yang paling banyak dipilih pada rumah tangga pendapatan rendah yaitu kepulenan nasi sebanyak 33 orang dengan persentase $66 \%$, untuk rumah tangga pendapatan menengah yaitu atribut beras kepala sebanyak 29 orang dengan persentase $58 \%$, dan untuk pendapatan tinggi yaitu atribut daya tahan simpan nasi sebanyak 26 orang dengan persentase $52 \%$. Hal ini menunjukkan bahwa tingkat kesukaan para konsumen terhadap atribut-atribut beras pada kategori ini sangat bervariasi. Hasil penelitian ini senada dengan yang dilakukan oleh (Hendaris et al., 2013) yang menggarisbawahi bahwa kepunelan merupakan atribut penting.

Preferensi konsumen rumah tangga terhadap atribut beras untuk kategori biasa yang paling banyak dipilih pada rumah tangga pendapatan rendah yaitu volume keterkembagan sebanyak 33 orang dengan persentase $66 \%$, untuk rumah tangga pendapatan menengah yaitu atribut rasa nasi dan butir patah sebanyak 20 orang dengan persentase $40 \%$, dan untuk pendapatan tinggi yaitu atribut beras kepala sebanyak 28 orang dengan persentase $56 \%$. Hal ini menunjukkan bahwa tingkat kesukaan para konsumen terhadap atribut-atribut beras pada kategori ini sangat bervariasi.

Preferensi konsumen rumah tangga terhadap atribut beras untuk kategori tidak suka yang paling banyak dipilih pada rumah tangga pendapatan rendah yaitu butir menir sebanyak 16 orang dengan persentase $32 \%$, untuk rumah tangga pendapatan menengah yaitu atribut butir menir sebanyak 34 orang dengan persentase $68 \%$, dan untuk pendapatan tinggi yaitu atribut butir menir dan butir kapur sebanyak 9 orang dengan persentase $18 \%$. Hal ini menunjukkan bahwa tingkat kesukaan atribu beras pada kategori ini adalah sama, yang dimana para konsumen rumah tangga sama sama memilih atribut butir menir .

Preferensi konsumen rumah tangga terhadap atribut beras untuk kategori sangat tidak suka yang paling banyak dipilih pada konsumen rumah tangga pendapatan rendah yaitu butir kapur sebanyak 16 orang dengan persentase $32 \%$, untuk konsumen rumah tangga pendapatan menengah yaitu atribut butir kapur sebanyak 14 orang dengan persentase $28 \%$, dan untuk konsumen rumah tangga pendapatan tinggi tidak ada yang memilih atribut beras pada kategori ini. Hal ini menunjukkan bahwa tingkat kesukaan para konsumen rumah tangga konsumen pendapatan rendah dan menengah adalah sama yaitu pada atribut beras berupa butir kapur, sedangkan untuk konsumen rumah tangga pendapatan tinggi tidak ada yang memilih karena konsumennya lebih banyak memilih pada kategori biasa, suka dan sangat suka.

\section{KESIMPULAN}

Hal penting dari penelitian ini adalah karakteristik konsumen beras berdasarkan golongan pendapatan rumah tangga di Kota Palembang pada umumnya memiliki usia antara 1556 tahun, berjenis kelamin perempuan, berpendidikan dari yang tidak Bersekolah sampai ada yang Lulus Perguruan Tinggi, mayoritas berprofesi sebagai ibu rumah tangga dan BUMN, berpendapatan antara $<\mathrm{Rp} 1.000 .000$,- sampai dengan $>$ Rp10.000.000,- per bulan, dengan ratarata konsumsi beras antara 1-10 Kg/bulan sampai dengan 51-60 Kg/bulan. Selanjutnya atribut beras mencakup mencakup tingkat kepulenan nasi, daya tahan simpan nasi, rasa nasi, aromatic, jenis beras, volume keterkembangan, beras kepala, butir patah, butir menir, butir kapur, dan warna.

Preferensi konsumen berdasarkan atribut beras di Kota Palembang dikategorikan menjadi 2, yaitu berdasarkan tingkat kepentingan dan kesukaan atribut beras. Preferensi konsumen rumah tangga berdasarkan tingkat kepentingan atribut beras untuk kategori sangat penting yang paling banyak dipilih pada golongan pendapatan tinggi dan sedang adalah kualitas sebelum beras tersebut menjadi nasi, sedangkan golongan pendapatan rendah adalah factor ketahanan pada nasi.Preferensi konsumen rumah tangga berdasarkan tingkat kesukaan atribut beras untuk 
kategori sangat suka yang paling banyak dipilih pada golongan pendapatan tinggi adalah rasa nasi, untuk golongan pendapatan menengah adalah kepulenan nasi, dan golongan pendapatan rendah adalah kepulenan nasi dan beras kepala. Tingkat pendapatan ternyata berpengaruh terhadap tingkat kepentingan konsumen dalam memilih beras, dimana golongan menengah atas lebih menitik beratkan pada kualitas sebelum beras tersebut menjadi nasi. Sementara masyarakat pendapatan rendah mementingkan factor ketahanan nasi. Hal ini dikarenakan untuk masyarakat menengah ke atas jarang melakukan pengolahan sisa nasi menjadi bahan pangan (diversifikasi) seperti yang dilakukan oleh golongan masyarakat bawah.

\section{DAFTAR PUSTAKA}

BPS-Statistics Indonesia. (2018). Trends of Selected Socio-Economic Indicators of Indonesia (S. of S. P. and Services, Ed.). Jakarta: BPS - Statistics Indonesia.

BPS Sumatera Selatan. (2019). Pola Distribusi Perdagangan Komoditas Strategis Provinsi Sumatera Selatan Tahun 2017. Palembang: BPS.

Hendaris, T. W., Zakaria, W. A., \& Kasymir, E. (2013). Pola Konsumsi Dan Atribut-Atribut Beras Siger Yang Diinginkan Konsumen Rumah Tangga Di Kecamatan Natarkabupaten Lampung Selatan. JIIA (Jurnal Ilmu-Ilmu Agribisnis), 1(3), 232-237.

Kamila, F., \& Prasetyo, E. (2019). Analisis sikap konsumen pada pembelian beras (Kamila et al.) 9. Agrisocioeconomics, 3(1), 9-18.

Nurjaya, \& Maulida, N. (2018). Tingkat Kesukaan Konsumen Pada Atribut Beras. Agroscience, $8(1)$.

Sari PA. (2016). Analisis Perilaku Petani Dan Saluran Pemasaran Beras di Kecamatan Lempuing Kabupaten Ogan Komering Ilir. Fakultas Pertanian Universitas Sriwijaya.

Sugiono. (2015). Statistika Untuk Penelitian. Bandung: Penerbit Alfabeta.

Sumarwan, U., A. N. dan K. (2013). . Analisis proses keputusan pembelian, persepsi dan sikap konsumen terhadap beras organik di Jabotabek. J. Pangan, 22(2), 333-344.

Swastika, O. N., Yanto, T., \& Hartati, A. (2013). Performansi Kualitas Atribut Beras Organik Dan Tingkat Kepuasan Konsumen Beras Organik Di Kabupaten Sragen. Agrin, 17(2), 1410-1439. Retrieved from https://www.jurnalagrin.net/index.php/agrin/article/view/203/187

Syahrir, S. A. A. T. dan B. (2015). Preferensi Konsumen Beras Berlabel. Agriekonomika, 4(1). 